\title{
Host Specialization and Phylogenetic Diversity of Corynespora cassiicola
}

\author{
L. J. Dixon, R. L. Schlub, K. Pernezny, and L. E. Datnoff
}

First and fourth authors: University of Florida/IFAS, Plant Pathology Department, 1453 Fifield Hall, P.O. Box 110680, Gainesville 32611; second author: Western Pacific Tropical Research Center, University of Guam, UOG Station, Mangilao, Guam 96923; and third author: University of Florida/IFAS, Everglades Research and Education Center, Belle Glade 33630. Accepted for publication 5 April 2009.

\section{ABSTRACT}

Dixon, L. J., Schlub, R. L., Pernezny, K., and Datnoff, L. E. 2009. Host specialization and phylogenetic diversity of Corynespora cassiicola. Phytopathology 99:1015-1027.

The fungus Corynespora cassiicola is primarily found in the tropics and subtropics, and is widely diverse in substrate utilization and host association. Isolate characterization within $C$. cassiicola was undertaken to investigate how genetic diversity correlates with host specificity, growth rate, and geographic distribution. C. cassiicola isolates were collected from 68 different plant species in American Samoa, Brazil, Malaysia, and Micronesia, and Florida, Mississippi, and Tennessee within the United States. Phylogenetic analyses using four loci were performed with 143 Corynespora spp. isolates, including outgroup taxa obtained from culture collections: $C$. citricola, $C$. melongenae, $C$. olivacea, $C$. proliferata, $C$. sesamum, and $C$. smithii. Phylogenetic trees were congruent from the ribosomal DNA internal transcribed spacer region, two

Corynespora cassiicola (Berk. \& M. A. Curtis) C. T. Wei, the type species of the genus, is one of $>100$ described Corynespora spp. delineated in part by host of isolation $(13,59)$. The fungus has been found on plant leaves, stems, and roots; nematode cysts; and human skin $(3,5,8,9,19,29,30,41)$. More than 530 plant species from 380 genera, including monocots, dicots, ferns, and one cycad, have been reported to support the growth of $C$. cassiicola $(47,49)$. The majority of isolates reported are obtained from discrete lesions or are supported by Koch's postulates and, therefore, are classified as pathogens $(2,3,7,9,17,21,22,24,31$, $32,41,48,51)$. Isolates obtained from dead organic material or that fail Koch's postulates are often reported and classified as saprotrophs on a given host $(6,19,24,26,27,34)$. Isolates obtained from living, nonsymptomatic tissue are also reported and are classified as endotrophs $(10,16,40,54)$. Some isolates show pathogenicity to a wide range of hosts, whereas others exhibit host specificity $(12,24,33,34,36,38,43,50,51,53)$. Others are only pathogenic when associated with wounding $(6,57)$.

The variability in host range within $C$. cassiicola is so great that grouping isolates based on host origin is problematic for predicting pathogenicity and genetic relatedness (45). Isolates with different pathogenicity profiles can be found on the same host (15). As many as eight different pathogenicity profiles were recognized among 28 isolates collected from Glycine max (soybean) in Mexico, Cucumis sativus (cucumber) in Florida, and

Corresponding author: L. J. Dixon; E-mail address: linleyjsmith@gmail.com

doi:10.1094/PHYTO-99-9-1015

This article is in the public domain and not copyrightable. It may be freely reprinted with customary crediting of the source. The American Phytopathological Society, 2009. random hypervariable loci (caa5 and ga4), and the actin-encoding locus actl, indicating a lack of recombination within the species and asexual propagation. Fifty isolates were tested for pathogenicity on eight known C. cassiicola crop hosts: basil, bean, cowpea, cucumber, papaya, soybean, sweet potato, and tomato. Pathogenicity profiles ranged from one to four hosts, with cucumber appearing in 14 of the 16 profiles. Bootstrap analyses and Bayesian posterior probability values identified six statistically significant phylogenetic lineages. The six phylogenetic lineages correlated with host of origin, pathogenicity, and growth rate but not with geographic location. Common fungal genotypes were widely distributed geographically, indicating long-distance and global dispersal of clonal lineages. This research reveals an abundance of previously unrecognized genetic diversity within the species and provides evidence for host specialization on papaya

Additional keywords: target spot.

diverse hosts in Nigeria (34). An isolate collected from Carica papaya (papaya) debris was pathogenic on Solanum lycopersicum (tomato) and cucumber but not papaya, indicating that individual isolates can be both saprotrophic and pathogenic, depending on the host substrate (24). The host specificity and severity of the fungus on Lantana camara (lantana) in Brazil has led to the discovery that Corynespora cassiicola may be useful as a bioherbicide (36). Based on the vast number of weeds that serve as hosts and the host specificity of some isolates, there is potential for the discovery of additional isolates useful for biological control of weeds (51).

Past assessments of genetic diversity within C. cassiicola were largely limited to Hevea brasiliensis (rubber) isolates from Asia and were based on random amplified polymorphic DNA (RAPD) techniques, which are problematic with respect to repeatability and homology assessment (20). RAPD studies provide evidence for host specialization on individual rubber clones and papaya but do not indicate geographic associations between isolates $(44,46)$. Restriction fragment length polymorphism (RFLP) of the ribosomal (r)DNA internal transcribed spacer (ITS) locus resulted in monomorphic patterns with diverse isolates $(1,44,45)$. However, an isolate from rubber clone RRIM 2020 had a distinct RFLP pattern after digestion of the amplified rDNA ITS locus with HaeIII (1).

C. cassiicola is a ubiquitous phytopathogen reported to cause major economic losses in $>70$ countries. The aim of this study was to expand our knowledge of the genetic variability among $C$. cassiicola isolates through the use of improved molecular methods and a large pool of diverse isolates. To accomplish these goals, we obtained 143 isolates from varied hosts and geographic locations. Isolates of target spot of Ocimum basilicum (basil), Phaseolus vulgaris (bean), Vigna unguiculata (cowpea), cucumber, papaya, soybean, Ipomoea batatas (sweet potato), tomato, 
and other crops were of particular focus because of the research implications for resistance breeding and disease management. Correlations among isolates' host, geographic locations, growth rate, pathogenicity profiles, and genotypes were investigated. This research will ideally improve disease management by identifying sources of inoculum and isolates for breeding and bioherbicide efforts.

\section{MATERIALS AND METHODS}

Collection of fungal isolates. $C$. cassiicola isolates were collected from diverse plant hosts during 5-day visits to locations in the Pacific-American Samoa (AS), Hawaii (HI), Palau (PW), Pohnpei (PH), Saipan (SN), and Yap (YP)—in summer 2005. More extensive surveys were conducted in Florida (FL) and Guam (GU) from 2004 to 2006 . Host priority was given to basil, bean, cowpea, cucumber, papaya, soybean, sweet potato, and tomato plants as well as other susceptible crops, weeds, and naturalized or indigenous hosts of $C$. cassiicola. Leaves were collected and placed into individual plastic bags in the field. Priority was given to samples with discrete lesions, a common disease symptom of Corynespora leaf spot. In the laboratory, the leaves were placed abaxial side up in petri dishes lined with moistened paper towels and examined daily over the course of 4 days. Sporulating isolates arising from discrete lesions within $24 \mathrm{~h}$ were designated "lesioned" and those from lesion-free host tissue were designated "healthy" (Table 1). Sporulating isolates arising from decayed tissue with nondiscrete lesions or those that required $48 \mathrm{~h}$ or more to sporulate were designated "necrotic." Conidia were captured at the end of a teasing needle and transferred to antibiotic V8 agar slants (340 $\mathrm{ml}$ of V8 juice, $660 \mathrm{ml}$ of water, $3 \mathrm{~g}$ of $\mathrm{CaCO}_{3}, 17 \mathrm{~g}$ of agar, and ampicillin or kanamycin at $100 \mu \mathrm{g} / \mathrm{ml})$, left at room temperature until colonies reached at least $5 \mathrm{~cm}$ in diameter, covered with autoclaved mineral oil, and stored at $5^{\circ} \mathrm{C}$.

To obtain a more global sampling of $C$. cassiicola, isolates were requested from individual researchers (Table 1). Isolates of different Corynespora spp. were also obtained from culture collections to serve as potential outgroups. Cultures were singlespored after they were received (47). A complete list of the isolates used in this study, along with their hosts, geographic locations, and description of the host tissue from which they were isolated, can be found in Table 1.

Fungal cultures and extraction of genomic DNA. Genomic DNA from 143 isolates in long-term storage at $5^{\circ} \mathrm{C}$ was purified and amplified using Extract-N-Amp (Sigma-Aldrich, St. Louis) according to the manufacturer's specifications. To increase the likelihood that sequence data represent phylogenetic relationships, both variable (caa5, ga4, and act 1 ) and conserved (rDNA ITS) loci were chosen for analysis. The following primers were used for polymerase chain reaction (PCR) amplification: ITS1 and ITS4 (58) for the ITS region, including the 5.8S rRNA coding region; ACT-512F and ACT-783R (4) for the single-copy nuclear actin locus act1; GA4-F (5'-CCT GCT CCG ACT TTG TTG AG$\left.3^{\prime}\right)$ and GA4-R (5'-GTC TGG GAG CAG CAA AGA CT-3') for the random hypervariable ga4 locus; and CAA5-F (5'-GTC CAC AAG TGG AAC CTC GT-3') and CAA5-R (5'-CCT CGT CTG CCA GTT CTT CT-3') for the random hypervariable caa5 locus (47). Primers for the ga4 and caa5 loci were designed from a $C$. cassiicola microsatellite library enriched for GA and CAA repeats. "Hot-start" PCR was performed with a MyCycler thermocycler (Bio-Rad Laboratories, Hercules, CA) with a program consisting of initial denaturation for $3 \mathrm{~min}$ at $94^{\circ} \mathrm{C}$; followed by 30 cycles of $30 \mathrm{~s}$ at $94^{\circ} \mathrm{C}, 30 \mathrm{~s}$ at $58^{\circ} \mathrm{C}$, and $45 \mathrm{~s}$ at $72^{\circ} \mathrm{C}$; and a final cycle of $5 \mathrm{~min}$ at $72^{\circ} \mathrm{C}$ for the rDNA ITS, ga4, and caa 5 loci. For the actl locus, the program was identical except for an annealing temperature of $61^{\circ} \mathrm{C}$. PCR products were purified using the QIAquick PCR purification Kit (QIAGEN Inc., Valencia, CA) according to the manufacturer's instructions. The purified products were then quantified on $1 \%$ ethidium bromide-stained agarose gels. Sequencing of the DNA samples was performed using the same primers that were used for amplification at the University of Florida DNA Sequencing Core Laboratory using ABI Prism BigDye Terminator cycle sequencing protocols (part number 4303153) developed by Applied Biosystems (PerkinElmer Corp., Foster City, CA). Sequencing reactions were performed on an ABI Prism 3130 Genetic Analyzer (Applied Biosystems, Foster City, CA) following the manufacturer's protocols.

Phylogenetic analyses. Four loci (rDNA ITS, caa5, ga4, and actl) from 143 isolates were sequenced. Forward and reverse sequences from each PCR product were proofread and contiged in Sequencher 4.8 (Gene Codes Corporation, Ann Arbor, MI) and samples with ambiguous bases were sent for resequencing or PCR reactions were repeated. Multiple alignments from each locus were executed separately with ClustalX 1.83.1 (56) and the alignments were inspected and adjusted manually using MacClade 4.08 OS X (28). A partition-homogeneity test (incongruence length-difference test [ILD]) was implemented to evaluate the homogeneity of different data partition subsets using PAUP* v4.0b10 (55). The test implemented 1,000 replicates (heuristic search; random simple sequence additions; tree-bisection reconnection (TBR); max-trees $=1,000)$. Comparisons were evaluated using a threshold of $P<0.001$ and were made between all data partitions.

Neighbor joining (NJ) and maximum parsimony (MP) analyses were conducted for each data set using PAUP* v4.0b10 (55). C. smithii IMI 5649b, C. citricola IMI 211585, C. proliferata CBS 112393, C. citricola CBS 169.77, and C. olivacea CBS 291.74 were selected as outgroups for rooting purposes. For the NJ analyses, default settings were used except ties were broken randomly by initial seed.

As a result of long computational time, MP analyses were conducted in the following manner. An initial heuristic search was conducted with one random addition replicate, TBR branch swapping, and the MulTrees option (saving all optimal trees) in effect. Using the above settings, a second heuristic search was conducted with 1,000 random addition replicates and saving no more than 10 trees with a score greater than or equal to the best tree score from the previous analysis. In all analyses, gaps were treated as missing data. Strict consensus trees were generated from analyses with multiple equally parsimonious trees. For all MP analyses, statistical support for nodes was estimated using MP bootstrap (BS) replicates (14). For the combined data set, BS estimates were obtained using 1,000 replicates, each with 100 random taxon addition replicates and saving no more than 1,500 trees per bootstrap replicate, TBR branch swapping, and the MulTrees option in effect.

All data were also analyzed by Bayesian inference (BI) methods with MrBayes v3.1.2 (18,42). An appropriate model of evolution (under the AIC criterion) was selected for each data partition using the program Modeltest v3.4 (39). All Bayesian analyses (individual loci and combined data) were conducted while retaining the appropriate model for each data partition. Two replicates of Markov Chain Monte Carlo were implemented with four heated chains and trees sampled every 1,000th generation for one million generations. To set the generation time, the number of generations required to achieve standard deviations of split frequencies of $\leq 0.01$ was determined. A plot of likelihood scores at each sampling point was used to estimate burn-in. A $50 \%$ majority rule consensus tree was generated from the remaining trees, in which the percentage of nodes recovered represented their posterior probability (PoPr). Congruent nodes resulting from the NJ, MP, and BI analyses of the combined molecular data were used to assign isolates to a phylogenetic lineage (PL). Only isolates that fell within clades of high support (BS value $>70$ and PoPr value $>95$ ) were assigned to a PL. 
TABLE 1. Origin and characteristics of Corynespora isolates used for phylogenetic analyses

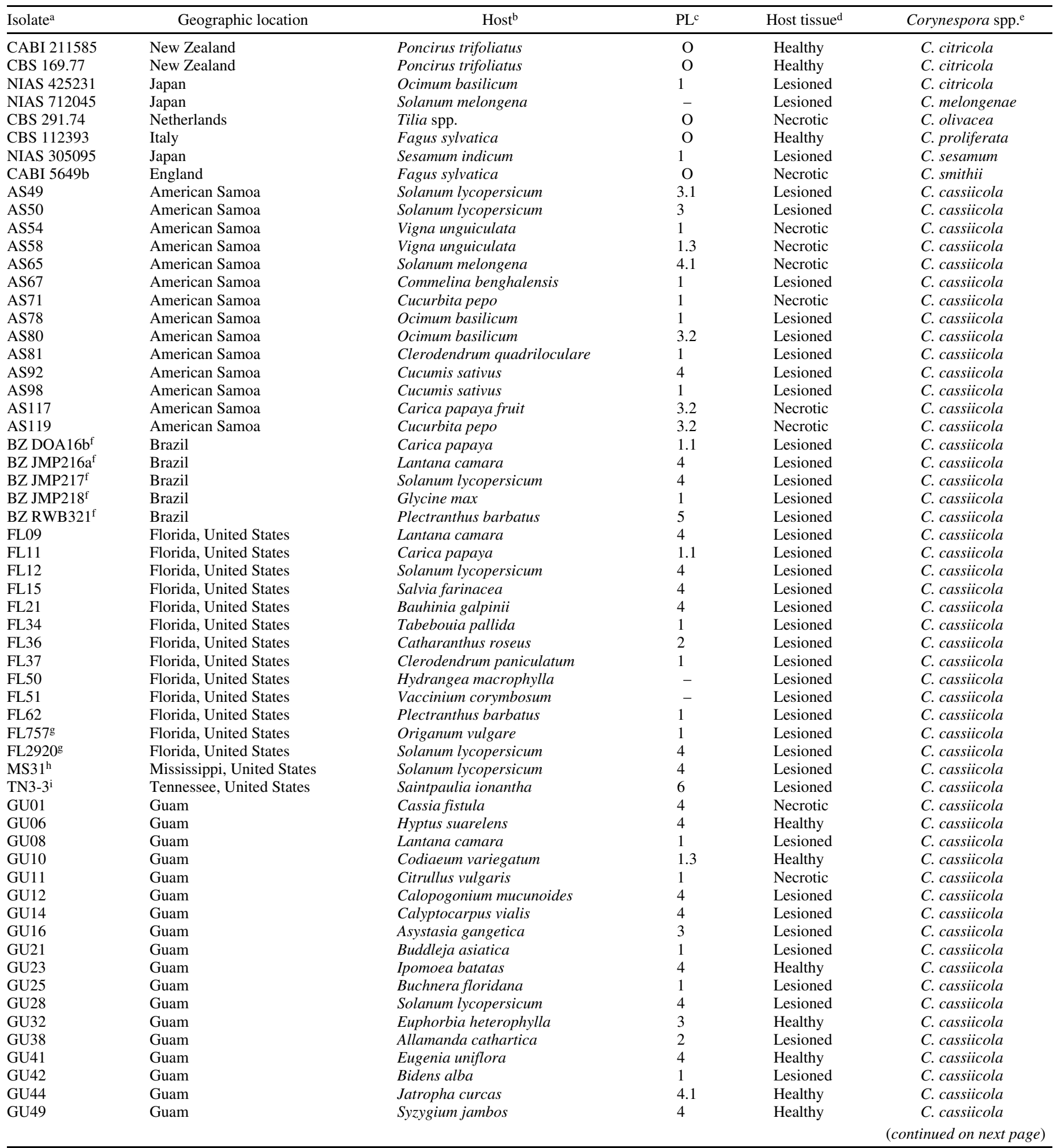

${ }^{a}$ Isolate designation.

b Original host from which the isolate was collected.

${ }^{c}$ Phylogenetic lineage (PL) designation within Corynespora cassiicola based on combined sequence analysis of ribosomal DNA internal transcribed spacer region, caa5, ga4, and act. Five isolates were defined as outgroups $(\mathrm{O})$; - indicates that the isolate's clade was not statistically significant.

${ }^{\mathrm{d}}$ Description of host tissue prior to incubation.

e Corynespora spp. designation. Three isolates from the NIAS culture collection $(305095,425231$, and 712045$)$ are likely misidentified because they grouped with C. cassiicola isolates according to sequence data and morphology. They are labeled herein according to the original culture collection designations, though they should be reclassified as C. cassiicola. The remaining isolates were collected as part of this study or obtained from other researchers and are listed according to geographic location.

${ }^{\mathrm{f}}$ Received from Empresa Brasileira de Pesquisa Agropecuária-Embrapa.

${ }^{g}$ Received from John Scott, Gulf Coast Research and Education Center, University of Florida.

${ }^{\mathrm{h}}$ Received from David Ingram, Central Mississippi Research and Extension Center

i Received from Justin S. Clark, University of Tennessee.

j Received from Safiah Atan, Rubber Research Board. 
TABLE 1. (continued from preceding page)

\begin{tabular}{|c|c|c|c|c|c|}
\hline Isolate $^{\mathrm{a}}$ & Geographic location & $\operatorname{Host}^{\mathrm{b}}$ & $\mathrm{PL}^{\mathrm{c}}$ & Host tissue $^{\mathrm{d}}$ & Corynespora spp..$^{\mathrm{e}}$ \\
\hline GU51 & Guam & Ochrosia oppositifolia & 1 & Healthy & C. cassiicola \\
\hline GU55 & Guam & Calopogonium mucunoides & 3.2 & Lesioned & C. cassiicola \\
\hline GU65 & Guam & Passiflora foetida & 3.3 & Healthy & C. cassiicola \\
\hline GU68 & Guam & Moringa oleifera & 3 & Healthy & C. cassiicola \\
\hline GU70 & Guam & Solanum melongena & 1.4 & Healthy & C. cassiicola \\
\hline GU79 & Guam & Acanthus ilicifolius & 3 & Healthy & C. cassiicola \\
\hline GU83 & Guam & Euphorbia heterophylla & 4.1 & Healthy & C. cassiicola \\
\hline GU90 & Guam & Stachytarpheta jamaicensis & 1 & Lesioned & C. cassiicola \\
\hline GU92 & Guam & Carica papaya & 1.1 & Lesioned & C. cassiicola \\
\hline GU93 & Guam & Capsicum annum & 1.3 & Healthy & C. cassiicola \\
\hline GU98 & Guam & Spathodea campanulata & 4 & Lesioned & C. cassiicola \\
\hline GU99 & Guam & Saintpaulia ionantha & 6 & Lesioned & C. cassiicola \\
\hline GU101 & Guam & Euphorbia milii & 4 & Necrotic & C. cassiicola \\
\hline GU102 & Guam & Phaseolus vulgaris & 4 & Necrotic & C. cassiicola \\
\hline GU103 & Guam & Pilea nummulariifolia & 2 & Healthy & C. cassiicola \\
\hline GU104 & Guam & Macroptilium atropurpureum & 1.3 & Lesioned & C. cassiicola \\
\hline GU107 & Guam & Mikania micrantha & 4 & Lesioned & C. cassiicola \\
\hline GU109 & Guam & Bauhinia galpinii & 3 & Lesioned & C. cassiicola \\
\hline GU110 & Guam & Plectranthus ambionicus & 3 & Lesioned & C. cassiicola \\
\hline GU111 & Guam & Manihot esculenta & 4.1 & Healthy & C. cassiicola \\
\hline GU112 & Guam & Glycine $\max$ & 3.3 & Healthy & C. cassiicola \\
\hline GU114 & Guam & Teramnus labialis & 3.1 & Healthy & C. cassiicola \\
\hline GU115 & Guam & Vitex parviflora & 1 & Lesioned & C. cassiicola \\
\hline GU120 & Guam & Plectranthus barbatus & 4 & Lesioned & C. cassiicola \\
\hline GU128 & Guam & Solanum lycopersicum & 4 & Lesioned & C. cassiicola \\
\hline GU136 & Guam & Ficus benjamani & 4.2 & Healthy & C. cassiicola \\
\hline HI01 & Oahu, Hawaii, United States & Ocimum basilicum & 1 & Lesioned & C. cassiicola \\
\hline MY CBPP & Malaysia & Hevea brasiliensis, clone unknown & 1.2 & Lesioned & C. cassiicola \\
\hline MY CLN16 & Malaysia & Hevea brasiliensis RRIM2020 & 1.2 & Lesioned & C. cassiicola \\
\hline MY CSB12j & Malaysia & Hevea brasiliensis RRIM 725 & 2 & Lesioned & C. cassiicola \\
\hline PH01 & Pohnpei & Carica papaya & 1.1 & Healthy & C. cassiicola \\
\hline PW01 & Palau & Carica papaya & 1.1 & Lesioned & C. cassiicola \\
\hline PW12 & Palau & Carica papaya & 1.1 & Lesioned & C. cassiicola \\
\hline PW17 & Palau & Carica papaya & 1.1 & Lesioned & C. cassiicola \\
\hline PW20 & Palau & Carica papaya & 1.1 & Lesioned & C. cassiicola \\
\hline PW25 & Palau & Carica papaya & 1.1 & Lesioned & C. cassiicola \\
\hline PW27 & Palau & Carica papaya & 1.1 & Lesioned & C. cassiicola \\
\hline PW34 & Palau & Carica papaya & 1.1 & Lesioned & C. cassiicola \\
\hline PW37 & Palau & Carica papaya & 1.1 & Lesioned & C. cassiicola \\
\hline PW38 & Palau & Carica papaya & 1.1 & Lesioned & C. cassiicola \\
\hline PW43 & Palau & Carica papaya & 1.1 & Lesioned & C. cassiicola \\
\hline PW48 & Palau & Carica papaya & 1.1 & Lesioned & C. cassiicola \\
\hline PW53 & Palau & Carica papaya & 1.1 & Lesioned & C. cassiicola \\
\hline PW56 & Palau & Carica papaya & 1.1 & Lesioned & C. cassiicola \\
\hline PW57 & Palau & Solanum lycopersicum & 4 & Lesioned & C. cassiicola \\
\hline PW63 & Palau & Solanum lycopersicum & 4 & Lesioned & C. cassiicola \\
\hline PW69 & Palau & Piper betle & 2 & Healthy & C. cassiicola \\
\hline PW79 & Palau & Pilea microphylla & 2 & Lesioned & C. cassiicola \\
\hline PW80 & Palau & Episcia reptans & 1 & Lesioned & C. cassiicola \\
\hline PW83 & Palau & Episcia reptans & 1 & Lesioned & C. cassiicola \\
\hline PW87 & Palau & Cucumis sativus & 1 & Lesioned & C. cassiicola \\
\hline PW89 & Palau & Chromolaena odorata & 4 & Healthy & C. cassiicola \\
\hline PW91 & Palau & Luffa acutangula & 1 & Healthy & C. cassiicola \\
\hline PW92 & Palau & Catharanthus roseus & 1.3 & Lesioned & C. cassiicola \\
\hline PW94 & Palau & Stachytarpheta jamaicensis & 1 & Lesioned & C. cassiicola \\
\hline PW99 & Palau & Momordica charantia & 3 & Lesioned & C. cassiicola \\
\hline PW101 & Palau & Vigna unguiculata & 5 & Necrotic & C. cassiicola \\
\hline SN03 & Saipan & Momordica charantia & 1 & Lesioned & C. cassiicola \\
\hline SN05 & Saipan & Ipomoea batatas & 1 & Lesioned & C. cassiicola \\
\hline SN06 & Saipan & Luffa acutangula & 3.2 & Healthy & C. cassiicola \\
\hline SN07 & Saipan & Carica papaya & 1.1 & Healthy & C. cassiicola \\
\hline SN18 & Saipan & Carica papaya & 1.1 & Lesioned & C. cassiicola \\
\hline $\mathrm{SN} 24$ & Saipan & Solanum lycopersicum & 4 & Lesioned & C. cassiicola \\
\hline SN27 & Saipan & Solanum lycopersicum & 4 & Lesioned & C. cassiicola \\
\hline SN30 & Saipan & Solanum lycopersicum & 4 & Lesioned & C. cassiicola \\
\hline SN37 & Saipan & Vigna unguiculata & 4 & Necrotic & C. cassiicola \\
\hline SN40 & Saipan & Cucumis sativus & 4 & Lesioned & C. cassiicola \\
\hline SN43 & Saipan & Saintpaulia ionantha & 3 & Lesioned & C. cassiicola \\
\hline SN48 & Saipan & Coccinia grandis & 3.3 & Healthy & C. cassiicola \\
\hline SN53 & Saipan & Carica papaya & 1.1 & Lesioned & C. cassiicola \\
\hline SN59 & Saipan & Lantana camara & 1.5 & Lesioned & C. cassiicola \\
\hline SN64 & Saipan & Asystasia gangetica & 5.1 & Lesioned & C. cassiicola \\
\hline SN69 & Saipan & Pachystachys lutea & 3.1 & Lesioned & C. cassiicola \\
\hline
\end{tabular}


Pathogenicity analyses. Of the 143 Corynespora isolates used in the phylogenetic study, 50 were selected for pathogenicity profiling against eight known economically important susceptible crop plants commonly grown in the survey regions (Table 2). Isolates were chosen from hosts used in the inoculation studies and to represent diverse PLs. A factorial experiment was arranged in a completely randomized design with four replications and with isolates and crop plants as factors. Each isolate was spray inoculated onto four replicates of susceptible plants: 8-week-old basil 'Italian Large Leaf' (Ba), bean 'Bush Kentucky Wonder' (Be), cowpea 'California black-eye' (Co), cucumber 'Straight 8' (Cu), soybean 'AG00901' (So), and tomato 'Rutgers' (To) seedlings; 8-week-old sweet potato 'Beauregard' (Sw) cuttings; and 12-week-old papaya 'HI Sunrise' (Pa) seedlings. The experiment was repeated twice, and the data from the two experiments were pooled for analysis. Data were analyzed by analysis of variance (ANOVA) and treatment means compared by Fisher's least significant difference (FLSD, $P \leq 0.05$ ) with SAS (SAS Institute, Inc., Cary, NC).

To increase colony sporulation for inoculum preparation, aerial mycelium from 10-day-old V8 agar plates $(100 \mathrm{~mm})$ were gently scraped with a glass cover slip to flatten and then placed under constant cool-white fluorescent light ( $\approx 25$ lux) (35). Three days later, the surface of the agar was scraped with a glass cover slip and the resulting mycelia were blended in $200 \mathrm{ml}$ of sterile distilled water for $2 \mathrm{~s}$ and filtered through three layers of cheesecloth. Spore concentration was determined using a hemacytometer and adjusted to 20,000 spores $/ \mathrm{ml}$ using sterile distilled water. One drop of Tween 20 per $100 \mathrm{ml}$ was added to the inoculum. Plants preconditioned on a moisture bench under constant moisture conditions were sprayed with the spore suspension until runoff $(\approx 500 \mathrm{ml})$, making sure that both leaf surfaces were fully covered. Plants were kept on a mist bench and rated for disease 7 days after inoculation using the disease rating system developed by Onesirosan et al. (33): $0=$ symptomless: no lesions on leaves or stems; 1 = weakly virulent or hypersensitive response: a few to many nonexpanding pinpoint lesions; 2 = moderately virulent: many expanding lesions, some coalescing, but not resulting in blight; and 3 = highly virulent: lesions spreading to form large areas of dead tissue resulting in a blighting effect. Disease incidence (I) was recorded as the number of plants within a treatment with symptoms (a disease rating of $\geq 1$ ). Disease severity ( $\mathrm{S}$ ) was calculated by averaging the disease rating of symptomatic plants within a treatment. For comparative purposes, a disease severity rating for each host was determined by averaging the severity ratings of all isolates that exhibited symptoms on that host.

Each isolate was assigned a pathogenicity profile (PP) based on the number of susceptible host species. A host species was considered susceptible if at least one of the replicates from the two experiments (total of eight plants) received a disease rating of 2 or 3 . PPs were converted to a binary character matrix so that each isolate received either a zero or a one for each host. A zero was assigned to isolates that were nonpathogenic or weakly pathogenic on a given host (all replications with disease ratings of 0 or 1). A one was assigned to isolates that were pathogenic on a given host (at least one replication with a disease rating of 2 or 3 ). Unweighted pair group method with arithmetic mean (UPGMA) trees were constructed from the binary matrix, and internal support for nodes were estimated using bootstrap analyses with 100,000 reps and an UPGMA algorithm (Fig. 1). The tree topology was visually compared with the PL designation of each isolate tested (Fig. 1). PPs were also visually mapped on the fourlocus combined BI phylogenetic tree (Fig. 2).

Growth rate analyses. Growth rates of 77 isolates (selected to represent diverse hosts and geographic locations) were tested at 23 and $33^{\circ} \mathrm{C}$, which are known extremes for the fungus (37). A factorial experiment was arranged in a completely randomized design with three replications. The factors studied were isolates of C. cassiicola and temperature. Small pieces of aerial mycelium were extracted from monosporic cultures in long-term storage with tweezers and placed onto V8 agar plates. After 5 days, when the colonies had grown beyond their mineral oil, six 4-mm agar plugs were cut from the actively growing edge of each colony. Single plugs were transferred to the center of six V8 agar plates. Three replicate plates of each isolate were immediately placed in growth chambers at 23 and $33^{\circ} \mathrm{C}$ under $12 \mathrm{~h}$ of alternating fluorescent light $(\approx 25 \mathrm{lux})$ and darkness. For each plate, the average of two colony diameters at $90^{\circ}$ from each other was recorded at 48, 72, 96, 120, 144, and $166 \mathrm{~h}$. Increase in colony diameter $(\mathrm{mm})$ was plotted against time $(\mathrm{h})$ and a line of best fit was generated for each replicate. Using SAS Statistical Software (version 8), the slope of the line of best fit $\left(R^{2}>0.98\right)$ was determined and used to compare variation within replications with variation between isolates. The experiment was repeated with five randomly selected isolates to assess repeatability. Data were analyzed by ANOVA and treatment means compared by FLSD $(P \leq$ $0.05)$ with SAS. For comparison purposes, treatment means were pooled according to host, geographic location, and PL and their means and standard errors were calculated and plotted (Fig. 3).

\section{RESULTS}

Phylogenetic analyses. Sequence are available in GenBank (accession numbers rDNA ITS: FJ852574 to FJ852716; GA4: FJ852717 to FJ852859; CAA5: FJ852860 to FJ853002; and FJ853003 to FJ853141). The final combined data set used for analysis contained 2,136 aligned characters (Table 3). ILD tests of the combined matrix showed no significant difference in the phylogenetic signal of the four regions (rDNA ITS versus caa5 versus $g a 4$ versus act, $P=0.983$ ). The general time reversible (GTR) model incorporating a proportion of invariable sites and a distribution of rates at variable sites modeled on a discrete gamma distribution $(\mathrm{GTR}+\mathrm{I}+\Gamma$ ) was selected by Modeltest for each of the four gene partitions. The corresponding model for each locus was applied to all BI analyses and the combined data set was partitioned. The first $25 \%$ of the total number of generations was discarded as burn-in. Tree topologies resulting from NJ, MP, and $\mathrm{BI}$ analyses recovered essentially the same well-supported nodes. The analyses revealed six PLs with high statistical support (BS value $>70$ and PoPr value $>95$ ) (Fig. 2).

TABLE 1. (continued from preceding page)

\begin{tabular}{|c|c|c|c|c|c|}
\hline Isolate $^{\mathrm{a}}$ & Geographic location & $\operatorname{Host}^{\mathrm{b}}$ & $\mathrm{PL}^{\mathrm{c}}$ & Host tissue $^{\mathrm{d}}$ & Corynespora spp. ${ }^{\mathrm{e}}$ \\
\hline YP01 & Yap & Carica papaya & 1.1 & Lesioned & C. cassiicola \\
\hline YP08 & Yap & Carica papaya & 1.1 & Lesioned & C. cassiicola \\
\hline YP17 & Yap & Carica papaya & 1.1 & Lesioned & C. cassiicola \\
\hline YP27 & Yap & Cucumis sativus & 2 & Lesioned & C. cassiicola \\
\hline YP29 & Yap & Cucumis sativus & 1 & Lesioned & C. cassiicola \\
\hline YP41 & Yap & Saintpaulia ionantha & 2 & Lesioned & C. cassiicola \\
\hline YP42 & Yap & Solanum lycopersicum & 3 & Lesioned & C. cassiicola \\
\hline
\end{tabular}


The rDNA ITS alignment was composed of 1,013 characters, 400 of which are an insertion in the outgroup taxon $C$. smithii. Of the 612 remaining characters, 141 were variable and 107 were informative. The taxa from the NIAS culture collection, $C$. sesamum 305095, C. citricola 425231, and C. melongenae 712045, appear to be misidentified and are, in fact, C. cassiicola, based on $100 \%$ identity in rDNA ITS sequences and similar morphology. When the outgroup taxa $C$. citricola, $C$. olivacea, $C$. proliferata, and $C$. smithii were removed from the analyses, the rDNA ITS sequences of the $C$. cassiicola isolates contained only 3 informative characters out of 584 bases. Two of these characters (base pairs 158 and 497) separate the isolates into three distinct haplotypes-CA, CG, and TG (no haplotype TA) - that are congruent with the PLs in the four-locus combined analysis. All isolates with haplotype CA are in PL4; all isolates with haplotype TG are in PL1; and isolates with haplotype CG are in PLs 2, 3, 5, and 6. CG is likely the ancestral haplotype, present in all outgroups except for $C$. proliferata (which is haplotype CA). The third informative character in the rDNA ITS sequence alignment is base pair 123, which is a $\mathrm{T}$ in the majority of isolates but a $\mathrm{C}$ in isolates PW101 (PL5), RWB321 (PL5), SN64 (PL5.1), and TN13-3 (PL6). It is this character (base pair 123) that caused the

TABLE 2. Pathogenicity profiles for 50 isolates of Corynespora cassiicola ${ }^{\mathrm{a}}$

\begin{tabular}{|c|c|c|c|c|c|c|c|c|c|c|c|c|c|c|c|c|c|c|c|}
\hline \multirow[b]{2}{*}{ Path Pro ${ }^{\mathrm{b}}$} & \multirow[b]{2}{*}{$\mathrm{PL}^{\mathrm{c}}$} & \multirow[b]{2}{*}{ Isolate $^{\mathrm{d}}$} & \multirow[b]{2}{*}{$\mathrm{H}^{\mathrm{e}}$} & \multicolumn{2}{|c|}{$\mathrm{Ba}$} & \multicolumn{2}{|c|}{$\mathrm{Be}$} & \multicolumn{2}{|c|}{ Co } & \multicolumn{2}{|c|}{$\mathrm{Cu}$} & \multicolumn{2}{|c|}{$\mathrm{Pa}$} & \multicolumn{2}{|c|}{ So } & \multicolumn{2}{|c|}{ Sw } & \multicolumn{2}{|c|}{ To } \\
\hline & & & & I & $\mathrm{S}$ & I & $\mathrm{S}$ & I & $\mathrm{S}$ & I & $\mathrm{S}$ & I & $\mathrm{S}$ & I & $\mathrm{S}$ & I & $\mathrm{S}$ & I & $\mathrm{S}$ \\
\hline $\mathrm{BaCoCu}$ & 1 & AS78 & $\mathrm{Ba}$ & 5 & 2.6 & 0 & - & 4 & 1.8 & 6 & 2.3 & 0 & - & 0 & - & 1 & 1.0 & 2 & 1.0 \\
\hline $\mathrm{BaCoCu}$ & 1.3 & AS58 & Co & 6 & 2.3 & 0 & - & 3 & 2.3 & 6 & 3.0 & 0 & - & 0 & - & 0 & - & 7 & 1.0 \\
\hline $\mathrm{BaCoCu}$ & 1 & YP29 & $\mathrm{Cu}$ & 7 & 2.1 & 0 & - & 3 & 1.7 & 8 & 3.0 & 0 & - & 0 & - & 0 & - & 0 & - \\
\hline $\mathrm{BaCoCu}$ & 1 & AS71 & $\mathrm{Pu}$ & 8 & 2.1 & 0 & - & 2 & 2.0 & 7 & 1.3 & 0 & - & 1 & 1.0 & 0 & - & 2 & 1.0 \\
\hline $\mathrm{BaCoCuSo}$ & 1 & PW87 & $\mathrm{Cu}$ & 5 & 2.2 & 0 & - & 5 & 1.6 & 8 & 2.5 & 0 & - & 2 & 1.5 & 0 & - & 7 & 1.0 \\
\hline $\mathrm{BaCu}$ & 1 & HI01 & $\mathrm{Ba}$ & 4 & 2.5 & 0 & - & 0 & - & 7 & 3.0 & 0 & - & 0 & - & 1 & 1.0 & 8 & 1.0 \\
\hline $\mathrm{BaCu}$ & 1 & SN05 & Sw & 7 & 1.9 & 1 & 1.0 & 0 & - & 6 & 2.7 & 0 & - & 0 & - & 0 & - & 2 & 1.0 \\
\hline BaCuTo & 3 & AS50 & To & 5 & 2.2 & 0 & - & 2 & 1.0 & 6 & 2.7 & 0 & - & 1 & 1.0 & 2 & 1.0 & 8 & 3.0 \\
\hline BaCuTo & 3 & YP42 & To & 6 & 2.3 & 0 & - & 0 & - & 7 & 2.6 & 0 & - & 0 & - & 0 & - & 8 & 2.6 \\
\hline BaCuTo & 3.2 & AS80 & $\mathrm{Ba}$ & 5 & 1.8 & 0 & - & 0 & - & 8 & 2.5 & 0 & - & 1 & 1.0 & 0 & - & 8 & 2.8 \\
\hline BaCuTo & 3.2 & AS117 & $\mathrm{Pa}$ & 7 & 1.9 & 0 & - & 2 & 1.0 & 8 & 2.8 & 0 & - & 2 & 1.0 & 8 & 1.0 & 7 & 2.9 \\
\hline $\mathrm{BeCoCuSw}$ & 4 & SN37 & Co & 7 & 1.0 & 5 & 1.6 & 5 & 1.4 & 8 & 2.8 & 0 & - & 2 & 1.0 & 3 & 1.3 & 8 & 1.0 \\
\hline BeCuSwTo & 4 & JMP217 & To & 5 & 1.0 & 7 & 1.9 & 0 & - & 8 & 2.9 & 0 & - & 0 & - & 1 & 2.0 & 8 & 2.5 \\
\hline BeCuSwTo & 4 & GU102 & $\mathrm{Be}$ & 0 & - & 7 & 1.3 & 0 & - & 8 & 2.6 & 0 & - & 0 & - & 2 & 1.5 & 8 & 2.5 \\
\hline BeCuSwTo & 4 & SN40 & $\mathrm{Cu}$ & 0 & - & 6 & 1.3 & 0 & - & 8 & 2.5 & 0 & - & 0 & - & 1 & 2.0 & 8 & 2.6 \\
\hline BeCuTo & 4 & PW57 & To & 0 & - & 6 & 1.7 & 0 & - & 8 & 2.1 & 0 & - & 2 & 1.0 & 0 & - & 8 & 3.0 \\
\hline $\mathrm{CoCu}$ & 1 & AS98 & $\mathrm{Cu}$ & 0 & - & 5 & 1.0 & 6 & 1.8 & 8 & 2.6 & 0 & - & 0 & - & 0 & - & 7 & 1.0 \\
\hline $\mathrm{CoCu}$ & 1 & YP26 & $\mathrm{Cu}$ & 0 & - & 7 & 1.0 & 4 & 1.5 & 7 & 2.4 & 0 & - & 0 & - & 8 & 1.0 & 8 & 1.0 \\
\hline $\mathrm{CoCu}$ & 1 & JMP218 & So & 0 & - & 0 & - & 7 & 2.1 & 8 & 3.0 & 0 & - & 0 & - & 7 & 1.0 & 7 & 1.0 \\
\hline $\mathrm{CoCu}$ & 1 & GU08 & $\mathrm{La}$ & 0 & - & 0 & - & 3 & 1.7 & 7 & 3.0 & 0 & - & 0 & - & 0 & - & 8 & 1.0 \\
\hline $\mathrm{Cu}$ & 1 & AS54 & Co & 0 & - & 1 & 1.0 & 0 & - & 8 & 3.0 & 0 & - & 1 & 1.0 & 8 & 1.0 & 1 & 1.0 \\
\hline $\mathrm{Cu}$ & 1 & YP51 & $\mathrm{Co}$ & 0 & - & 0 & - & 0 & - & 8 & 3.0 & 0 & - & 0 & - & 7 & 1.0 & 1 & 1.0 \\
\hline $\mathrm{CuPa}$ & 1.1 & DOA16b & $\mathrm{Pa}$ & 7 & 1.0 & 0 & - & 0 & - & 8 & 1.1 & 8 & 2.3 & 0 & - & 8 & 1.0 & 1 & 1.0 \\
\hline $\mathrm{CuPa}$ & 1.1 & FL11 & $\mathrm{Pa}$ & 0 & - & 5 & 1.0 & 0 & - & 8 & 1.3 & 7 & 2.6 & 0 & - & 0 & - & 8 & 1.0 \\
\hline $\mathrm{CuPa}$ & 1.1 & PH01 & $\mathrm{Pa}$ & 1 & 1.0 & 1 & 1.0 & 0 & - & 7 & 1.1 & 6 & 1.8 & 0 & - & 0 & - & 8 & 1.0 \\
\hline CuSo & 3.3 & GU112 & So & 0 & - & 0 & - & 5 & 1.0 & 8 & 2.8 & 0 & - & 1 & 2.0 & 1 & 1.0 & 2 & 1.0 \\
\hline $\mathrm{CuSw}$ & 2 & YP27 & $\mathrm{Cu}$ & 1 & 1.0 & 0 & - & 2 & 1.0 & 6 & 2.8 & 0 & - & 0 & - & 5 & 1.4 & 2 & 1.0 \\
\hline $\mathrm{CuSw}$ & 2 & YP59 & Sw & 2 & 1.0 & 0 & - & 1 & 1.0 & 7 & 2.6 & 0 & - & 0 & - & 6 & 1.4 & 7 & 1.0 \\
\hline $\mathrm{CuSw}$ & 1.5 & SN59 & $\mathrm{La}$ & 1 & 1.0 & 5 & 1.0 & 0 & - & 8 & 2.8 & 0 & - & 0 & - & 7 & 1.3 & 7 & 1.0 \\
\hline CuSwTo & 4 & PW63 & To & 4 & 1.0 & 0 & - & 7 & 1.0 & 8 & 2.6 & 0 & - & 0 & - & 1 & 2.0 & 8 & 3.0 \\
\hline CuSwTo & 4 & SN24 & To & 0 & - & 0 & - & 0 & - & 8 & 2.5 & 0 & - & 0 & - & 2 & 1.5 & 8 & 2.6 \\
\hline CuSwTo & 4 & SN27 & To & 5 & 1.0 & 0 & - & 0 & - & 8 & 3.0 & 0 & - & 0 & - & 5 & 1.2 & 8 & 2.9 \\
\hline CuSwTo & 4 & GU23 & Sw & 0 & - & 0 & - & 7 & 1.0 & 8 & 2.4 & 0 & - & 0 & - & 5 & 1.8 & 8 & 2.9 \\
\hline CuSwTo & 4 & FL09 & $\mathrm{La}$ & 0 & - & 1 & 1.0 & 0 & - & 8 & 1.4 & 0 & - & 2 & 1.0 & 3 & 1.3 & 8 & 2.8 \\
\hline CuTo & 3 & AS49 & To & 0 & - & 0 & - & 0 & - & 4 & 2.8 & 0 & - & 0 & - & 1 & 1.0 & 7 & 2.6 \\
\hline CuTo & 3.1 & AS119 & $\mathrm{Pu}$ & 0 & - & 0 & - & 0 & - & 8 & 2.3 & 0 & - & 1 & 1.0 & 7 & 1.0 & 8 & 2.5 \\
\hline CuTo & 4 & FL12 & To & 0 & - & 5 & 1.0 & 5 & 1.0 & 8 & 3.0 & 0 & - & 2 & 1.0 & 1 & 1.0 & 8 & 3.0 \\
\hline CuTo & 4 & FL2920 & To & 4 & 1.0 & 0 & - & 0 & - & 8 & 2.0 & 0 & - & 0 & - & 0 & - & 8 & 2.6 \\
\hline CuTo & 4 & MS31 & To & 0 & - & 7 & 1.0 & 8 & 1.0 & 8 & 2.8 & 0 & - & 0 & - & 1 & 1.0 & 8 & 2.3 \\
\hline CuTo & 4 & GU128 & To & 0 & - & 1 & 1.0 & 0 & - & 8 & 2.9 & 0 & - & 2 & 1.0 & 1 & 1.0 & 8 & 2.5 \\
\hline CuTo & 4 & SN30 & To & 0 & - & 0 & - & 0 & - & 8 & 3.0 & 0 & - & 2 & 1.0 & 2 & 1.0 & 8 & 3.0 \\
\hline CuTo & 4 & AS92 & $\mathrm{Cu}$ & 2 & 1.0 & 1 & 1.0 & 0 & - & 8 & 2.8 & 0 & - & 0 & - & 1 & 1.0 & 8 & 2.9 \\
\hline CuTo & 4 & JMP216a & $\mathrm{La}$ & 7 & 1.0 & 0 & - & 0 & - & 7 & 1.3 & 0 & - & 0 & - & 2 & 1.0 & 8 & 3.0 \\
\hline CuTo & 5 & PW101 & $\mathrm{Co}$ & 0 & - & 0 & - & 4 & 1.0 & 7 & 2.9 & 0 & - & 0 & - & 0 & - & 7 & 1.3 \\
\hline $\mathrm{Pa}$ & 1.1 & GU92 & $\mathrm{Pa}$ & 2 & 1.0 & 0 & - & 0 & - & 1 & 1.0 & 7 & 2.1 & 0 & - & 1 & 1.0 & 7 & 1.0 \\
\hline $\mathrm{Pa}$ & 1.1 & PW01 & $\mathrm{Pa}$ & 0 & - & 0 & - & 0 & - & 8 & 1.0 & 8 & 2.4 & 0 & - & 0 & - & 8 & 1.0 \\
\hline $\mathrm{Pa}$ & 1.1 & PW12 & $\mathrm{Pa}$ & 0 & - & 0 & - & 1 & 1.0 & 1 & 1.0 & 4 & 1.4 & 2 & 1.0 & 0 & - & 1 & 1.0 \\
\hline $\mathrm{Pa}$ & 1.1 & SN07 & $\mathrm{Pa}$ & 1 & 1.0 & 0 & - & 0 & - & 8 & 1.0 & 6 & 2.3 & 0 & - & 1 & 1.0 & 1 & 1.0 \\
\hline $\mathrm{Pa}$ & 1.1 & YP01 & $\mathrm{Pa}$ & 0 & - & 7 & 1.0 & 0 & - & 1 & 1.0 & 8 & 1.9 & 0 & - & 0 & - & 8 & 1.0 \\
\hline To & 4 & GU28 & To & 0 & - & 0 & - & 0 & - & 8 & 1.0 & 0 & - & 0 & - & 1 & 1.0 & 8 & 3.0 \\
\hline
\end{tabular}

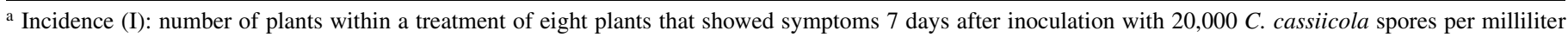
and severity (S): average disease rating of all the symptomatic plants. Disease rating: $0=$ symptomless; $1=$ nonpathogenic or weakly virulent, a few to many nonexpanding pinpoint lesions; 2 = moderately virulent, many expanding lesions, some coalescing, but not resulting in blight; 3 = highly virulent, lesions spreading to form large areas of dead tissue resulting in a blighting effect; and - indicates no symptomatic plants out of eight replicates.

b Pathogenicity profile (Path Pro): list of susceptible hosts (all plants with a disease rating >1).

${ }^{c}$ Phylogenetic lineage (PL) designation based on combined sequence analysis of ribosomal DNA internal transcribed spacer region, caa5, ga4, and act.

d C. cassiicola isolate designation.

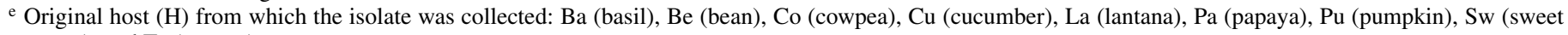
potato), and To (tomato). 
polymorphic band pattern observed by Atan and Hamid (1) in their RFLP analysis of the rDNA ITS region of rubber isolates using HaeIII (recognition sequence GGCC).

All PLs contain isolates from diverse geographic locations, indicating wide dispersal. Within PL1 (Fig. 2), a distinct clade with high statistical support (designated PL1.1) contains 23 isolates from papaya from diverse geographic locations. Pathogenicity studies with eight of these isolates support specificity to papaya. PL1.2 contains two isolates from Stachytarpheta jamaicensis collected from Guam and Palau. The genetic similarity of these isolates is supported by pathogenicity studies indicating host specificity to $S$. jamaicensis (51). Isolates from diverse hosts are present in PL1, including crops (basil, Momordica charantia [bitter melon], eggplant, cowpea, cucumber, oregano, papaya, Cucurbita pepo [pumpkin], rubber, soybean, sweet potato, and Citrullus vulgaris [watermelon]), ornamentals (Buddleja asiatica, Catharanthus roseus, Codiaeum variegatum, Plectranthus barbatus, and Tabebouia pallida), and weeds (Bidens alba, Buchnera floridana, Clerodendrum paniculatum, Commelina benghalensis, lantana, Macroptilium atropurpureum, Ochrosia oppositifolia, and Vitex parviflora). Missing from PL1 are isolates obtained from or that are pathogenic to tomato (Fig. 2; Table 2).

The nine isolates in PL2 are also globally distributed and include crops (cucumber, rubber, and sweet potato), ornamentals (African violet, Allamanda cathartica, Catharanthus roseus, and Pilea nummulariifolia), and weeds (Piper betle and Pilea microphylla). As in the case of PL1, there is a lack of isolates obtained from or pathogenic to tomato. In addition, only PLs 1 and 2 contain isolates from rubber.

Twenty-one globally distributed isolates are in PL3 and were collected from crops (basil, cucumber, pumpkin, bitter melon, soybean, and tomato), ornamentals (African violet, Bauhinia galpinii, Moringa oleifera, Pachystachys lutea, and Plectranthus ambionicus), and weeds (Acanthus ilicifolius, Asystasia gangetica, Calopogonium mucunoides, Coccinia grandis, Euphorbia heterophylla, Luffa acutangula, Passiflora foetida, and Teramnus labialis). These are hosts that may harbor isolates pathogenic to tomato. PL5 and PL6 group with PL3 with low support (MP BS value of 60). PL5 is highly supported and contains isolates collected from Plectranthus barbatus (Brazil), cowpea (Palau), and Asystasia gangetica (Saipan). PL6 contains Corynespora cassiicola isolates from African violet in Guam and Tennessee that are very similar in sequence, especially at the caa5 locus. Given the low level of sampling on African violet, it is impossible to differentiate between specialization on this host and plants that may have originated from the same horticultural source. African violet isolates from Saipan and Yap are found in PL3.

The majority of tomato isolates group in PL4 and are from diverse geographic locations, including American Samoa, Brazil, Florida, Guam, Mississippi, Palau, and Saipan. These 11 tomato isolates group with 25 isolates from crops (bean, Manihot esculenta [cassava], cucumber, and sweet potato), ornamentals (Bauhinia galpinii, Cassia fistula, Plectranthus barbatus, Eugenia uniflora, Ficus benjamani, Jatropha curcas, Salvia farinacea, and Syzygium jambos), and common weeds (Calopogonium тисиnoides, Calyptocarpus vialis, Chromolaena odorata, Euphorbia milii, E. heterophylla, Hyptus suarelens, lantana, Mikania micrantha, and Spathodea campanulata), which are likely inoculum sources for the initiation of disease on tomato.

The sister relationships between the PLs remain unsupported in the individual and combined locus analyses. In addition, the rDNA ITS region was the only locus that showed good support for Corynespora citricola, C. olivacea, $C$. proliferata, and $C$. smithii as sister taxa to the ingroup of $C$. cassiicola isolates. The phylogenetic placement of the outgroup taxa was not well supported in the combined analyses or the gat locus. The caa5 locus showed support for $C$. olivacea, $C$. proliferata, and $C$. smithii as basal to PLs 1, 2, 3, 5, and 6, but PL4 and C. citricola fell basal to that group. The apparent paraphyly of $C$. cassiicola at the caa5 locus may be a result of character variation that occurred at this locus before the species evolved. Additional loci containing characters that reveal the sister relationships of the PLs are needed in future phylogenetic analyses.

Pathogenicity analyses. As a result of screening 50 isolates for pathogenicity on eight index hosts, 16 unique PPs were found (Table 2). There were no statistically significant variations in pathogenicity when the experiment was repeated $(P=0.963)$; therefore, the data were combined. The null hypotheses of no pathogenicity differences among isolates, PL, and their interactions were rejected $(P<0.001)$, while the null hypothesis of no pathogenicity differences among replicates was accepted with a probability of 0.154 . The most common PP was CuTo, followed by $\mathrm{Pa}$ and CuSwTo (Table 2). Cucumber was the most susceptible host, with all isolates producing symptoms and a disease severity rating of 2.3. Tomato was also highly susceptible, with 49 of 50 isolates showing symptoms with a disease severity rating of 1.8 . All isolates pathogenic on papaya were originally isolated from papaya and were highly virulent to papaya (disease severity rating $=2.1$ ). Isolates pathogenic to basil, bean, cowpea, soybean, and sweet potato were less virulent on these hosts, with disease severity ratings $<1.5$.

There was a strong correlation between PP and PL $(P<0.001)$, (Figs. 1 and 2). Of 10 CuTo isolates, 7 were from PL4 and this lineage contained all CuSwTo and BeCuSwTo isolates. In PL4, all isolates but SN37 were highly virulent on tomato (disease severity ratings of 2.5 to 3 ) and all isolates but GU28 were pathogenic to cucumber (disease severity ratings of 1.3 to 3 ). In

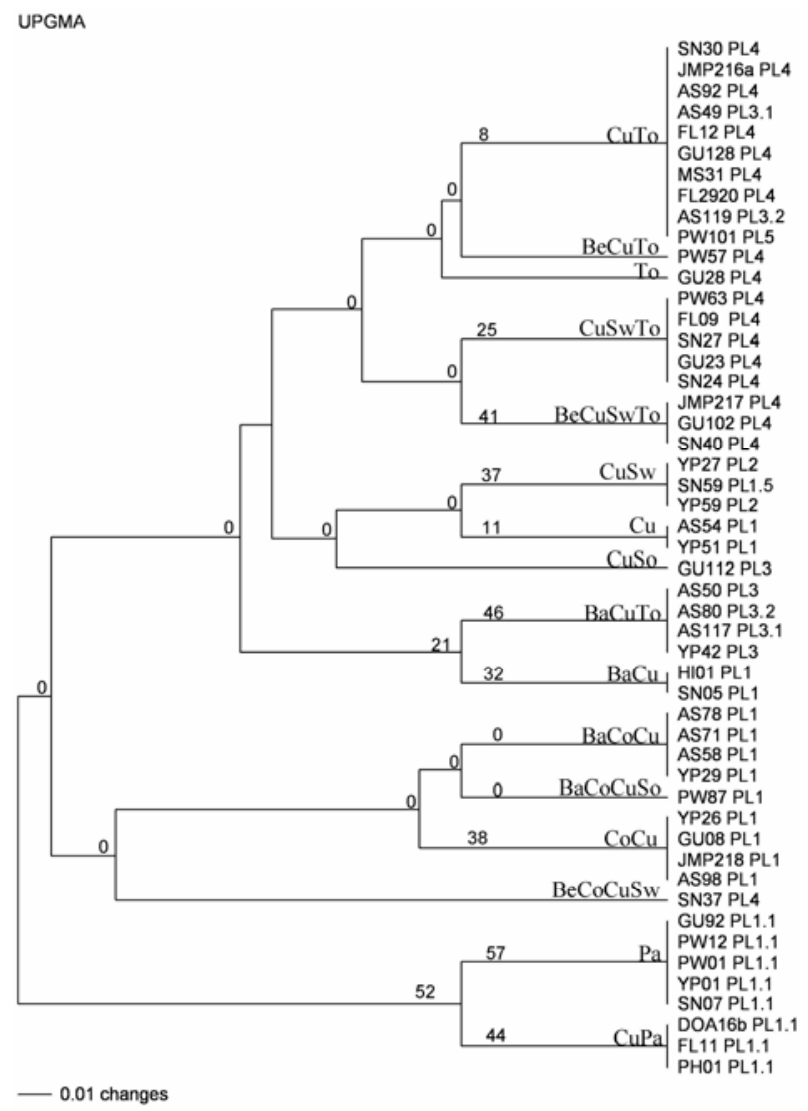

Fig. 1. Unweighted pair group method with arithmetic mean (UPGMA) dendrogram of 50 Corynespora cassiicola isolates based on pathogenicity profiles on eight crop plants: basil $(\mathrm{Ba})$, bean $(\mathrm{Be})$, cowpea $(\mathrm{Co})$, cucumber $(\mathrm{Cu})$, papaya $(\mathrm{Pa})$, soybean $(\mathrm{So})$, sweet potato $(\mathrm{Sw})$, and tomato $(\mathrm{To})$. Isolates are labeled with their phylogenetic lineage (PL) designation to demonstrate that isolates from the same PL cluster together. Statistical support for nodes by 100,000 UPGMA bootstrap repetitions is indicated. 


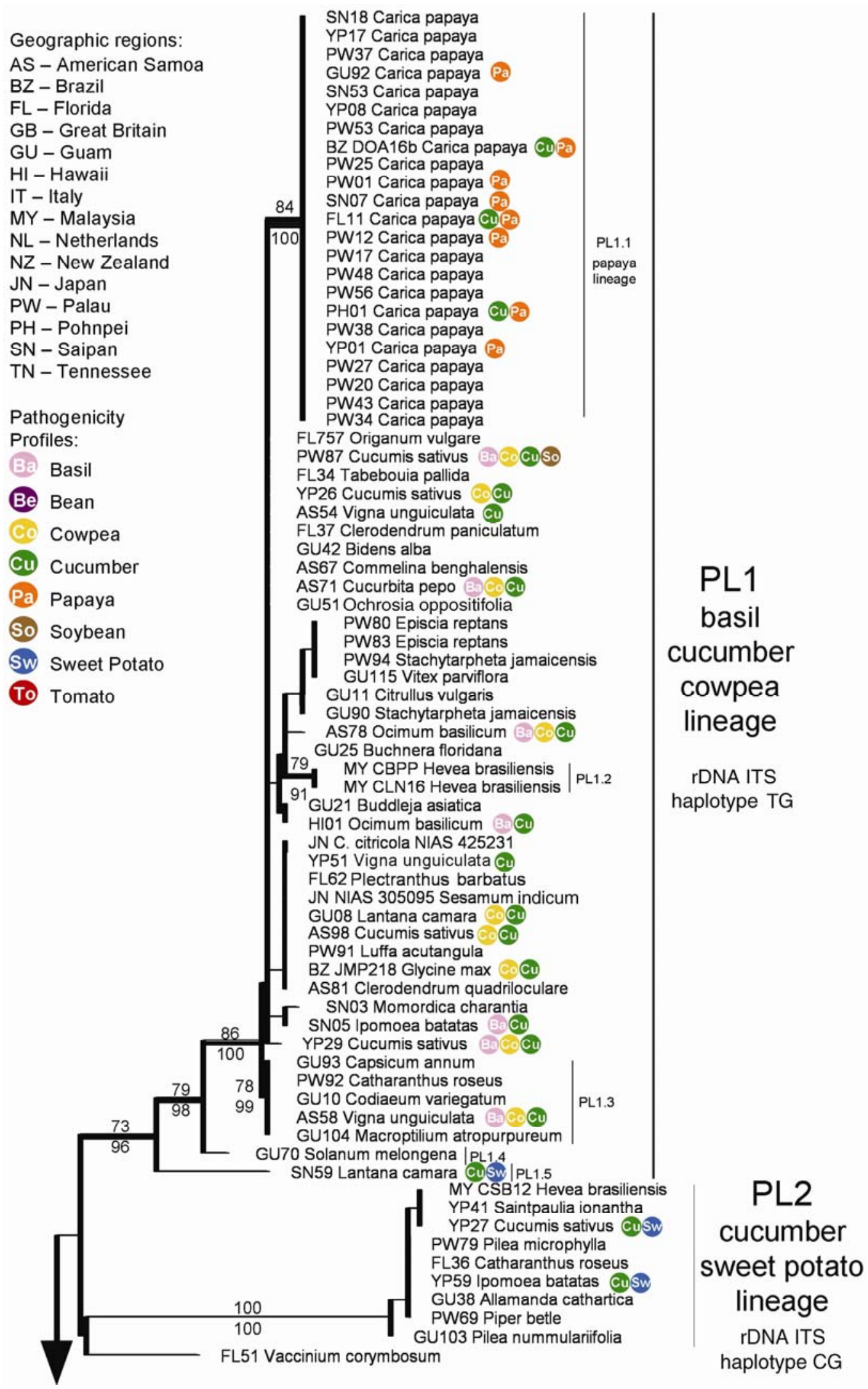

(Continued on next page)

Fig. 2. Majority rule (50\%) consensus tree phylogram from Bayesian inference analysis of combined data from ribosomal DNA internal transcribed spacer (rDNA ITS), ga4, caa5, and actl sequences. Numbers above branches indicate maximum parsimony bootstrap $>70 \%$ and numbers below branches indicate posterior probability values $>0.90$. Phylogenetic lineage (PL) indicates clades of high support. The branch length for outgroups Corynespora olivacea and C. proliferata was shortened in half to increase readability. Of the total 143 isolates, 50 were spray inoculated on eight crop plants to determine pathogenicity profiles. rDNA ITS haplotype designation is based on two mutations at base pairs 158 and 278 in a 584 base pair rDNA ITS alignment with only C. cassiicola taxa represented (no outgroups). 
addition, the only isolates pathogenic to bean were from PL4, although these five isolates were weakly virulent (disease severity ratings of 1.3 to 1.9 ).

In PL3, all isolates were strongly virulent to cucumber (disease severity ratings of 2.3 to 2.8 ) and six of seven isolates were strongly virulent to tomato (disease severity ratings of 2.5 to 3 ).
Four of the six isolates also were pathogenic to basil and all $\mathrm{BaCuTo}$ isolates were from PL3 (Fig. 1).

All isolates from PL2 had pathogenicity profile $\mathrm{CuSw}$ and this profile was unique to isolates from PLs 2 and 1.5 (Fig. 1). In addition, isolates collected in the field from papaya in PL1.1 were specific to papaya in pathogenicity studies, although these isolates

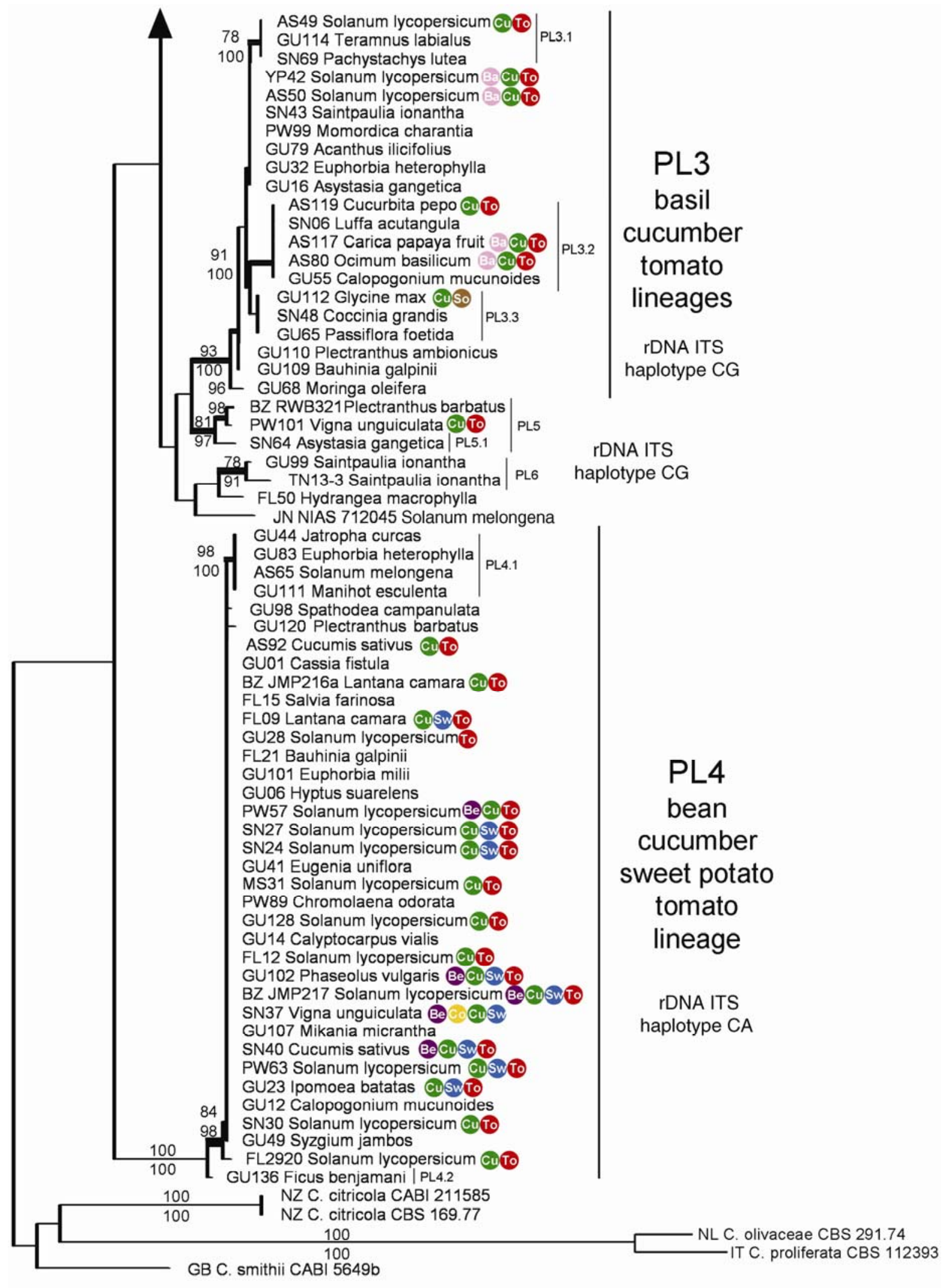

- 0.0005 substitutions/site

Fig. 2. (Continued from previous page) 
were weakly virulent on cucumber, with disease severity ratings of $\leq 1.3$ (Table 2). Excluding PL1.1, all isolates from PL1 were pathogenic to cucumber (disease severity ratings of 1.3 to 3 ), 9 of 13 were pathogenic to cowpea, and 7 were pathogenic to basil. The only other host susceptible to isolates from PL1 was soybean, which was only weakly susceptible when inoculated with isolate PW87. The only isolate tested from PL5 (PW101) was weakly pathogenic on the host from which it was isolated (cowpea) but was virulent to cucumber and tomato.

Growth rate analyses. The null hypotheses of no growth rate differences among isolates, PL, temperatures, and their interactions were rejected $(P<0.001)$, while the null hypothesis of no growth rate differences among repetitions was accepted with a probability of 0.755 (Fig. 3). There were no statistically significant variations in growth rate for the five randomly selected isolates in which the growth analyses were repeated $(P<0.001)$. Apart from isolate $\mathrm{PH} 01$, all isolates grew faster at 23 than at $33^{\circ} \mathrm{C}$. At $23^{\circ} \mathrm{C}$, isolate growth rate ranged from 0.148 to 0.474 , with an overall mean of $0.387 \pm 0.048$. At $33^{\circ} \mathrm{C}$, isolate growth rate ranged from 0.138 to 0.415 , with an overall mean of $0.296 \pm$ 0.07 . At $23^{\circ} \mathrm{C}$, there were 29 significantly different growth rates and, at $33^{\circ} \mathrm{C}$ there were 39 significantly different growth rates, and it appears that there is a continuum in growth rates within the species. Among the fastest growing isolates at both temperatures were FL37, GU99, GU90, AS71, AS67, HI01, SN03, and SN37 and the slowest growing were GU120, JMP216a, JMP217, and AS117. Of note was the fact that PH01, the slowest growing isolate at $23^{\circ} \mathrm{C}$, was ranked 36 th at $33^{\circ} \mathrm{C}$, and $\mathrm{AS} 119$, the slowest growing isolate at $33^{\circ} \mathrm{C}$, was ranked 13 th at $23^{\circ} \mathrm{C}$.

Growth rate was correlated with temperature, isolate, geographic location, PL, and host and all interactions were significant $(P<0.001)$. Isolates from the host genera Clerodendrum, Stachytarpheta, and Macroptilium were among the fastest growing at both temperatures (Fig. 3A). In addition, isolates from the host genera Salvia, Eugenia, Plectranthus, and Allamanda were among the slowest growing at both temperatures. Isolates from the host genera Cucurbita, Pilea, Spathodea, Phaseolus, and Carica grew proportionally faster at $33^{\circ} \mathrm{C}$ when compared with isolates from other genera, indicating a greater tolerance to warmer temperatures. Isolates from the host genera Plectranthus, Allamanda, Solanum, Bauhinia, and Tabebouia grew proportionally slower at $33^{\circ} \mathrm{C}$ compared with isolates from other genera, indicating a lesser tolerance to warmer temperatures. Isolates collected from American Samoa and Hawaii grew fastest at $23^{\circ} \mathrm{C}$ (Fig. 3B). Isolates from Pohnpei, Brazil, Florida, and Malaysia had slower growth rates at both temperatures. Isolates collected from American Samoa, Hawaii, and Malaysia grew proportionately much faster at 23 than at $33^{\circ} \mathrm{C}$, which may be a result of collecting at higher elevations where temperatures are cooler. Isolates from PLs 6 and 1 grew fastest at both temperatures (Fig. $3 \mathrm{C})$. Isolates collected from papaya in PL1.1 grew proportionally faster at 33 compared with $23^{\circ} \mathrm{C}$, indicating a higher tolerance to warmer temperatures. Isolates from PLs 2 and 4 grew slowest at $23^{\circ} \mathrm{C}$ and isolates from PLs 3 and 5 grew slowest at $33^{\circ} \mathrm{C}$.
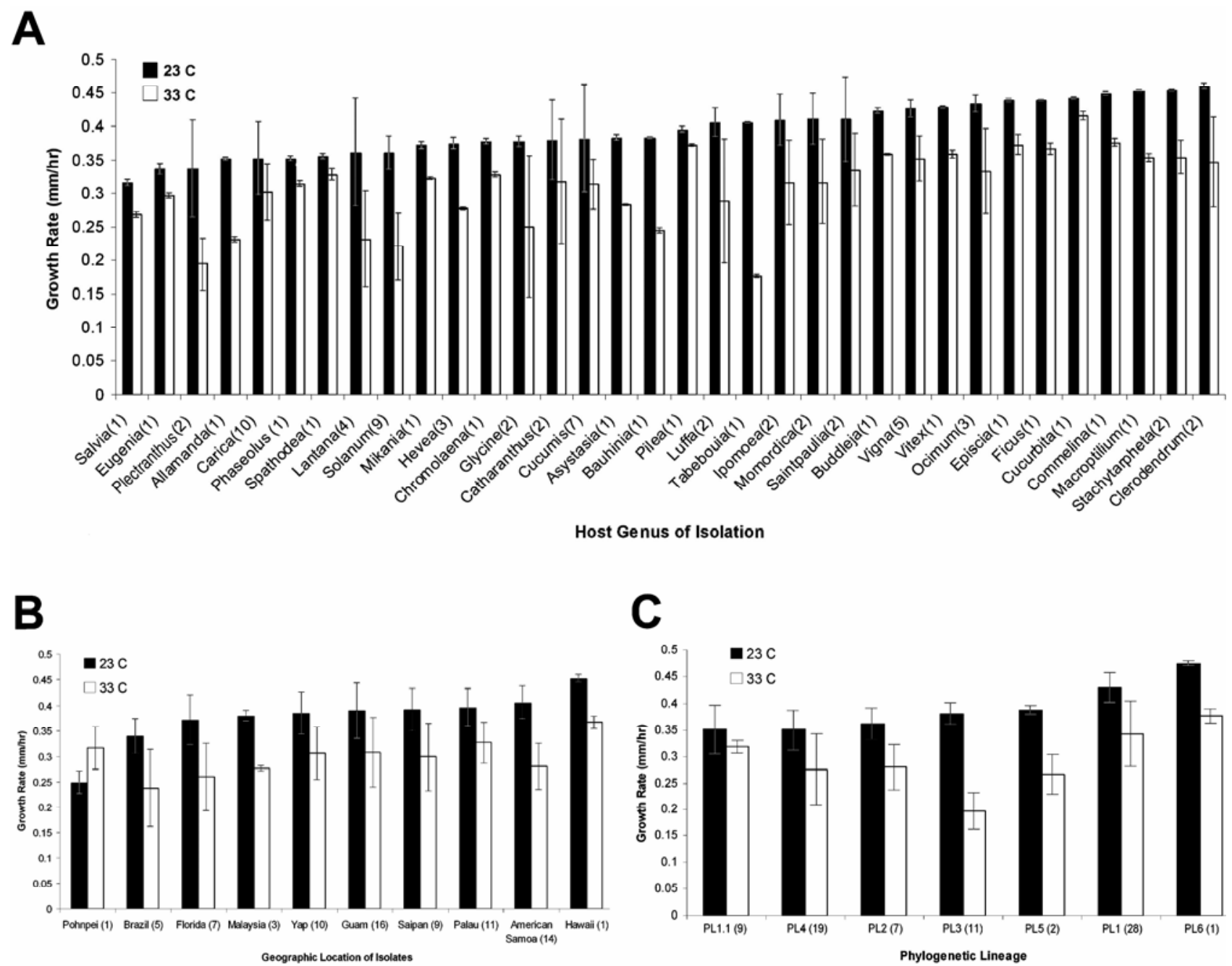

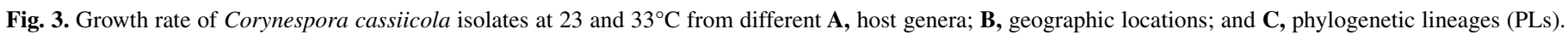
Bars represent \pm one standard deviation. 
Interestingly, isolates from PLs 3 and 5 group together with low bootstrap support (MP BS value of 67) and have similar growth rates at both temperatures.

\section{DISCUSSION}

The current study presents the first robust phylogeny using globally distributed $C$. cassiicola isolates. Based on sequence data from four loci, there is evidence for high genetic diversity within the species. This genetic diversity likely arose from accumulated mutations in clonal lineages based on the congruence of the phylogenetic trees from all four loci. All loci distinguish six clonal lineages within $C$. cassiicola and identical haplotypes are widely distributed geographically. The low level of sequence variation at the rDNA ITS region within the species relative to the outgroup Corynespora spp. suggests that these lineages are clonal populations rather than taxonomically distinct species (25).

The lack of correlation between phylogenetic data and geographic location provides evidence for recent global movement of isolates from all six PLs. In addition, geographically diverse isolates from the same host plant often share identical haplotypes, potentially indicating a degree of host specialization. For example, isolates collected from tomato in Brazil, Florida, Guam, Mississippi, Palau, and Saipan have identical haplotypes at all four loci. Although unlikely, the possibility remains that the fungus was distributed on tomato seed from the same source. Isolates collected from lantana in Florida and Brazil are also identical at all four loci, possibly indicating host specialization. Isolates collected from African violet in Guam and Tennessee are unique from all other isolates and nearly identical to each other at the loci sequenced. Isolates from different Pilea spp. in Guam and Palau are both in PL2. Given additional sequencing at loci with more resolution, isolates from the same host in different geographic locations may prove to be unique, indicating host specialization or recent global movement of plant material from a similar source. The most compelling evidence for host specialization is the host specificity of papaya isolates in the inoculation studies and the identical nucleotide sequences of geographically diverse papaya isolates (Fig. 2) (11). In addition, only isolates collected from papaya were found to be pathogenic on papaya.

Tomato isolates from diverse geographic locations are found only in PL3 and PL4 and only isolates from these lineages were pathogenic to tomato. Though there were no isolates collected from tomato in PL1 and PL2, isolates from these lineages produced a hypersensitive response on tomato, showing pinpoint lesions that were given a disease rating of one. These isolates may have lost the ability to cause disease on tomato either by mutation in the pathogen or acquired resistance in the host. Isolates from other hosts in PL3 and PL4 were also pathogenic to tomato in inoculation studies and, therefore, may serve as source hosts for target spot of tomato in the field. These hosts include common crops (basil, bean, bitter melon, cassava, cucumber, papaya, pumpkin, soybean, and sweet potato), weeds (Acanthus ilicifolius, Calopogonium mucunoides, Calyptocarpus vialis, Chromolaena odorata, Coccinia grandis, Euphorbia heterophylla, lantana, Macroptilium atropurpureum, Mikania micrantha, Momordica charantia, Passiflora foetida, and Teramnus labialis), and ornamentals (African violet, Asystasia gangetica, Bauhinia galpinii, Cassia fistula, Plectranthus barbatus, Eugenia uniflora, Euphorbia milii, Ficus benjamani, Hyptus suarelens, Jatropha curcas, lantana, Luffa acutangula, Moringa oleifera, Pachystachys lutea, Plectranthus ambionicus, Salvia farinacea, Spathodea campanulata, and Syzygium jambos). Based strictly on these data, control of target spot on tomato should involve isolation of tomato fields from these plant species when possible. Our inoculation methods were chosen to maximize consistency of results; however, disease incidence and severity values may be inflated compared with those that occur under natural field conditions.
There are at least 16 unique pathogenicity profiles within Corynespora cassiicola on the eight crop plants that were tested, and isolates from the same lineages show similar but not identical profiles (Figs. 1 and 2). Hosts susceptible to isolates from only two of the six lineages included basil, cowpea, sweet potato, and tomato. Isolates pathogenic to bean are only in PL4. Interestingly, the majority of isolates, excluding the isolates collected from papaya, were pathogenic on cucumber. These pathogenicity data are similar to those obtained by Onesirosan et al. (33) using $18 C$. cassiicola isolates from Nigeria, the southern United States, and Mexico in that both studies found isolates specific to papaya and cucumber. Likewise, both studies found that isolates pathogenic to tomato were likely to be pathogenic to several other hosts. The number of isolates screened compared with the number of unique pathogenicity profiles in both studies indicates that gains and losses of pathogenicity are common.

Though our phylogenetic data do not correlate with geography, growth rate experiments of ours and others provide evidence for adaptability of isolates to tropical and temperate environments. Using an isolate collected from tomato in Florida, Pernezny et al. (37) found the best colony growth occurred at $32^{\circ} \mathrm{C}$, whereas Sobers (52) reported an optimum growth rate at $24^{\circ} \mathrm{C}$ for Florida isolates collected from hydrangea and azalea. Jones and Jones (23) report higher disease severity on tomato inoculated and maintained at temperatures of 20 to $23^{\circ} \mathrm{C}$. In this study, two temperature extremes $\left(23\right.$ and $\left.33^{\circ} \mathrm{C}\right)$ were chosen in an attempt to discern between isolates adapted to temperate and tropical climates. Though the majority of isolates were collected from tropical climates, all isolates but one (PH01) grew faster at 23 than at $33^{\circ} \mathrm{C}$. Though only two temperatures were tested, the ideal temperature for colony growth is likely to be very near $23^{\circ} \mathrm{C}$ based on the fact that the majority of isolates grew better at 23 than at $33^{\circ} \mathrm{C}$, and the standard error of all isolates at $23^{\circ} \mathrm{C}$ was \pm 0.048 compared with \pm 0.07 for $33^{\circ} \mathrm{C}$. Growth rate did, however, correlate with PL $(P<0.001)$. Results indicate that isolates from PL1.1, PL4, and PL2 may be more adapted to warmer temperatures and isolates from PL5 and PL3 may be more adapted to cooler temperatures. Physiological traits that correlate with phylogenetic data, such as growth rate and pathogenicity profile, may be useful for isolate classification when further characterized.

The description of the original host tissue from which isolates were obtained in the field was useful in further understanding the diversity of trophic capabilities within $C$. cassiicola. Isolates collected from lesioned tissue were pathogenic to their original host 29 of 30 times. Interestingly, all isolates collected from healthy tissue were pathogenic to the original host of isolation, pointing toward the occurrence of latent infections in nature. AS54 (cowpea), AS58 (cowpea), AS117 (papaya fruit), and YP51

TABLE 3. Summational sequence data from four loci used to confirm the phylogenetic lineage of Corynespora cassiicola isolates

\begin{tabular}{lrcccr}
\hline Locus & Total & Variable & Informative & Tree score & $\begin{array}{c}\text { No. of } \\
\text { trees }^{\text {a }}\end{array}$ \\
\hline Combined $^{\text {b }}$ & 2,136 & 248 & 174 & 330 & 7,430 \\
rDNA ITS $^{\text {rDNA ITS }}$ & 1,013 & 135 & 100 & 158 & 9,990 \\
rDN $^{\text {ga4 }}$ & 584 & 4 & 3 & 4 & 1 \\
ga4 $^{\mathrm{c}}$ & 414 & 31 & 25 & 40 & 9,530 \\
caa5 $^{\text {caa5 }}$ & 414 & 28 & 25 & 36 & 9,560 \\
act1 $^{\text {c }}$ & 366 & 38 & 34 & 52 & 40 \\
act $^{\text {c }}$ & 366 & 37 & 32 & 46 & 12 \\
\hline
\end{tabular}

a Number of maximum parsimony trees.

${ }^{\mathrm{b}}$ Combined loci: ribosomal DNA internal transcribed spacer region (rDNA ITS), ga4, caa5, and act1.

${ }^{c}$ Locus analyzed with only Corynespora cassiicola taxa represented (no outgroups). 
(cowpea), which were all collected from necrotic tissue, were nonpathogenic when inoculated on their original hosts, indicating saprophytic growth in the field. Based on these data, it is likely that individual isolates have the ability to be pathogens, endotrophs, and saprotrophs on different hosts. In addition, a given host likely harbors pathogenic, endotrophic, and saprotrophic isolates of $C$. cassiicola.

These studies have shown that the rDNA ITS sequence will be useful for the initial screening of isolates and for isolate selection for resistance breeding. The rDNA ITS region was useful for the grouping of isolates into three groups based on two mutations at base pairs 158 and 278: PL1 (haplotype TG); PL4 (haplotype CA); and PLs 2, 3, 5, and 6 (haplotype CG). These haplotypes correlate with phylogenetic data from the combined four-locus data set (Fig. 2). For example, isolates from PL1 (rDNA ITS haplotype TG) should be used to screen for resistance to target spot in papaya. In contrast, isolates from PLs 3 and 4 (rDNA ITS haplotypes $\mathrm{CG}$ and $\mathrm{CA}$ ) should be used to screen for resistance to target spot in tomato. In addition, genotyping by restriction digest of the amplified rDNA ITS region is possible now that specific polymorphisms have been identified and mapped. For example, use of the enzyme $\mathrm{HpyCH} 4 \mathrm{~V}$ (recognition sequence TGCA) will cut in two positions in haplotypes CA and CG, but only one position in haplotype TG. Additionally, this research identified isolates with the same unique genotype found in Atan and Hamid's (1) RFLP analysis of the rDNA ITS region using HaeIII. However, only 4 of the 143 isolates we sequenced shared this polymorphism at base pair 123, rendering RFLP analysis of the rDNA ITS region using HaeIII ineffective for distinguishing among the majority of isolates.

It is hoped that this research will aid others in unraveling the many complexities that remain to be discovered with respect to $C$. cassiicola and its associated diseases. Despite evidence for host specificity on papaya, the combined pathogenicity and phylogenetic data indicate that there are many hosts with the potential to harbor $C$. cassiicola isolates pathogenic to susceptible crops such as basil, cucumber, and tomato. Although informative, it fails to explain why $C$. cassiicola is rare on all cultivated crops in Hawaii except basil or why, on Guam, outbreaks of target on cucumber are sporadic. Finally, further investigations are needed to determine the role played by the fungus's endotrophic and saprotrophic capabilities within its associated disease cycles.

\section{ACKNOWLEDGMENTS}

Funding and support was made possible by the United States Department of Agriculture (USDA) Special Grant Program for Tropical and Subtropical Agriculture Research, the University of Florida, IFAS, EREC, the Florida Tomato Committee, the University of Guam, Guam Cooperative Extension, and the USDA IPM 3-D and Hatch funds. We thank the Department of Plant Pathology, University of Florida, for financial and operational support.

\section{LITERATURE CITED}

1. Atan, S., and Hamid, N. H. 2003. Differentiating races of Corynespora cassiicola using RAPD and internal transcribed spacer markers. J. Rubber Res. 6:58-64.

2. Blazquez, C. H. 1972. Target spot of tomato. Plant Dis. Rep. 56:243-245.

3. Boosalis, M. G., and Hamilton, R. I. 1957. Root and stem rot of soybean caused by Corynespora cassiicola. Plant Dis. Rep. 41:8:696-698.

4. Carbone, I., and Kohn, L. M. 1999. A method for designing primer sets for speciation studies in filamentous ascomycetes. Mycologia 91:553-556.

5. Carris, L. M., and Glawe, D. A. 1986. Isolation of the soybean pathogens Corynespora cassiicola and Phialophora gregata from cysts of Heterodera glycines in Illinois. Mycologia 78:503-506.

6. Chase, A. R. 1982. Corynespora leaf spot of Aeschynanthus pulcher and related plants. Plant Dis. 66:739-740.

7. Chase, A. R. 1986. Corynespora bract spot of Euphorbia pulcherrima in Florida. Plant Dis. 70:1074.
8. Chase, A. R. 1987. Pages 22-23 in: Compendium of Ornamental Foliage Plant Diseases. American Phytopathological Society, St. Paul, MN.

9. Chase, A. R. 1993. Corynespora leaf spot and stem rot of Salvias. CFREC-Apopka Res. Rep. RH-93-12.

10. Collado, J., Platas, G., Gonzalez, I., and Pelaez, F. 1999. Geographical and seasonal influences on the distribution of fungal endotrophs in Quercus ilex. New Phytol. 144:525-532.

11. Couch, B. C., and Kohn, L. M. 2002. A multilocus gene genealogy concordant with host preference indicates segregation of a new species, Magnaporthe oryzae, from M. grisea. Mycologia 94:683-693.

12. Cutrim, F. A, and Silva, G. S. 2003. Pathogenicity of Corynespora cassiicola to different plant species. Fitopatol. Brasil. 28:193-194.

13. Ellis, M. B., and Holiday, P. 1971. Corynespora cassiicola (Berk. \& Curt.) Wei. Commonwealth Mycological Institute Descriptions of Fungi and Bacteria No. 31, Sheet 303.

14. Felsenstein, J. 1985. Confidence limit on phylogenies: an approach using the bootstrap. Int. J. Org. Evol. 39:783-791.

15. Furukawa, T., Ushiyama, K., and Kishi, K. 2008. Corynespora leaf spot of scarlet sage caused by Corynespora cassiicola. J. Gen. Plant Pathol. 74:117-119.

16. Gond, S. K., Verma, V. C., Kumar, A., Kumar, V., and Kharwar, R. N. 2007. Study of endotrophic fungal community from different parts of Aegle marmelos Correae (Rutaceae) from Varanasi (India). World J. Microbiol. Biotechnol. 23:1371-1375.

17. Hongn, S., Ramallo, A., Baino, O., and Ramallo, J. C. 2007. First report of target spot of Vaccinium corymbosum caused by Corynespora cassiicola. Plant Dis. 91:771.

18. Huelsenbeck, J. P., and Ronquist, F. 2001. MrBayes: Bayesian inference of phylogeny. Bioinformatics 17:754-755.

19. Hyde, K. D., McKenzie, E. H. C., and Dalisay, T. U. 2001. Saprobic fungi on bamboo culms. Fungal Divers. 7:35-48.

20. Isabel, N., Beaulieu, J., Theriault, P., and Bousquet, J. 1999. Direct evidence for biased gene diversity estimates from dominant random amplified polymorphic DNA (RAPD) fingerprints. Mol. Ecol. 8:477-483.

21. Jayasuryia, K. E., and Thennakoon, B. I. 2007. First Report of Corynespora cassiicola on Codiaeum variegatum (Croton) in Sri Lanka. Ceylon J. Sci. Biol. Sci. 36:138-141.

22. Jones, J. P. 1961. A leaf spot of cotton caused by Corynespora cassiicola. Phytopathology 51:305-308.

23. Jones, J. P., and Jones, J. B. 1984. Target spot of tomato: epidemiology, and control. Proc. Fla. State Hortic. Soc. 97:216-218.

24. Kingsland, G. C. 1985. Pathogenicity and epidemiology of Corynespora cassiicola in the Republic of the Seychelles. Acta. Hortic. (ISHS) 153:229-230.

25. Kohn, L. M. 2005. Mechanisms of fungal speciation. Annu. Rev. Phytopathol. 43:279-308.

26. Lee, S., Melnik, V., Taylor, J. E., and Crous, P. W. 2004. Diversity of saprobic hyphomycetes on Proteaceae and Restionaceae from South Africa. Fungal Divers. 17:91-114.

27. Lumyong, P., Photita, W., McKenzie, E. H. C., Hyde, K. D., and Lumyong, S. 2003. Saprobic fungi on dead wild banana. Mycotaxon 85:345-346.

28. Maddison, D. R., and Maddison, W. P. 2005. MacClade 4, version 4.08. Sinauer Associates, Sunderland, MA.

29. Mahgoub, E. S. 1969. Corynespora cassiicola, new agent of maduromycetoma. J. Trop. Med. Hyg. 1069:217-212.

30. Mathiyazhagan, S., Kavitha, K., Nakkeeran, S., Chandrasekar, G., Manian, K., Renukadevi, P., Krishnamoorthy, A. S., and Fernando, W. G. D. 2004. PGPR mediated management of stem blight of Phyllanthus amarus (Schum and Thonn) caused by Corynespora cassiicola (Berk and Curt) Wei. Arch. Phytopathol. Plant Prot. 37:183-199.

31. McGovern, R. J. 1994. Target spot of Catharanthus roseus caused by Corynespora cassiicola. Plant Dis. 78:830.

32. Olive, L. S., and Bain, D. C. 1945. A leafspot of cowpea and soybean caused by an undescribed species of Helminthosporium. Phytopathology 35:822-831.

33. Onesirosan, P. T., Arny, D. C., and Durbin, R. D. 1973. Target spot of tomato incited by Corynespora cassiicola (Berk. \& Curt.) Wei. Ph.D. dissertation, University of Wisconsin, Madison.

34. Onesirosan, P. T., Arny, D. C., and Durbin, R. D. 1974. Host specificity of Nigerian and North American isolates of Corynespora cassiicola. Phytopathology 64:1364-1367.

35. Onesirosan, P. T., Arny, D. C., and Durbin, R. D. 1975. Increasing sporulation of Corynespora cassiicola. Mycopathologia 55:121-123.

36. Pereira, J. M., Barreto, R. W., Ellison, C. A., and Maffia, L. A. 2003. Corynespora cassiicola f. sp. lantanae: a potential biocontrol agent from Brazil for Lantana camara. Biol. Control 26:21-31.

37. Pernezny, K., Datnoff, L. E., Rutherford, B., and Carroll, A. 2000. Relationship of temperature to growth, sporulation, and infection of tomato by the target spot fungus. Pages 16-19 in: Florida Tomato Committee Tomato Research Report for 2000. 
38. Poltronieri, L. S., Duarte, M. L. R., Alfenas, A. C., Trindade, D. R., and Albuquerque, F. C. 2003. Three new pathogens infecting Antilles cherry in the state of Para. Fitopatol. Brasil. 28:424-426.

39. Posada, D., and Crandall, K. A. 1998. Modeltest: testing the model of DNA substitution. Bioinformatics 14:817-818.

40. Promputha, I., Lumyong, A., Dhanasekaran, V. McKenzie, E. H. C., Hyde, K. D., and Jeewon, R. 2007. A phylogenetic evaluation of whether endotrophs become saprotrophs at host senescence. Microbiol. Ecol. 53:579-590.

41. Raffel, S. J., Kazmar, E. R., Winberg, R., Oplinger, E. S., Handelsman, J., Goodman, R. M., and Grau, C. R. 1999. First report of root rot of soybeans caused by Corynespora cassiicola in Wisconsin. Plant Dis. 83:696.

42. Ronquist, F., and Huelsenbeck, J. P. 2003. MrBayes3: Bayesian phylogenetic inference under mixed models. Bioinformatics 19:1572-1574.

43. Seaman, W. L., Shoemaker, R. A., and Peterson, E. A. 1965. Pathogenicity of Corynespora cassiicola on soybean. Can. J. Bot. 43:1461-1469.

44. Silva, W. P. K., Deverall, B. J., and Lyon, B. R. 1995. RFLP and RAPD analyses in the identification and differentiation of isolates of the leaf spot fungus Corynespora cassiicola. Aust. J. Bot. 43:609-618.

45. Silva, W. P. K., Deverall, B. J., and Lyon, B. R. 1998. Molecular, physiological and pathological characterization of Corynespora leaf spot from rubber plantations in Sri Lanka. Plant Pathol. 47:267-277.

46. Silva, W. P. K., Karunanayake, E. H., Wijesundera, R. L. C., and Priyanka, U. M. S. 2003. Genetic variation in Corynespora cassiicola: A possible relationship between host origin and virulence. Mycol. Res. 107:567-571.

47. Smith, L. J. Host range, phylogenetic and pathogenic diversity of Corynespora cassiicola (Berk. \& Curt.) Wei. Ph.D. dissertation, University of Florida, Gainesville.

48. Smith, L. J., Datnoff, L. E., Pernezny, K. L., Roberts, P. D., Rollins, J. A., Schlub, R. L., and Scott, J. W. 2006. Characterization and host-range of the tomato target spot fungus, Corynespora cassiicola and resistance of tomato cultivars. Pages 14-20 in: Florida Tomato Committee, Tomato Research Report for 2004-2005.
49. Smith, L. J., Datnoff, L. E., Pernezny, K. L., Rollins, J. A., and Schlub, R. L. 2008. Phylogenetic analyses of diverse Corynespora cassiicola isolates indicate an evolutionary correlation with host not geography. In: Meeting Abstracts, 9th Eur. Conf. Fungal Genet. Edinburgh.

50. Smith, L. J., and Schlub, R. L. 2004. Host range of Corynespora cassiicola and its occurrence on weeds, ornamentals and crops of Guam. (Abstr.) Phytopathology 94:S97.

51. Smith, L. J., and Schlub, R. L. 2005. Foliar fungi on weeds of Guam and the potential for Corynespora cassiicola as a bioherbicide for Stachytarpheta jamaicensis. (Abstr.) Phytopathology 95:S93.

52. Sobers, E. K. 1966. A leaf spot disease of azalea and hydrangea caused by Corynespora cassiicola. Phytopathology 59:455-457.

53. Spencer, J. A., and Walters, H. J. 1969. Variations in certain isolates of Corynespora cassiicola. Phytopathology 59:58-60.

54. Suryanarayanan, T. S., Murali, T. S., and Venkatesan, G. 2002. Occurrence and distribution of fungal endotrophs in tropical forests across a rainfall gradient. Can. J. Bot. 80:818-826.

55. Swofford, D. L. 2002. PAUP*. Phylogenetic Analysis Using Parsimony (*and Other Methods), version 4. Sinauer Associates, Sunderland, MA

56. Thompson, J. D., Gibson, T. J., Plewniak, F., Jeanmougin, F., and Higgins, D. G. 1997. The CLUSTAL_X windows interface: flexible strategies for multiple sequence alignment aided by quality analysis tools. Nucleic Acids Res. 25:4876-4882.

57. Volin, R. B., and Pohronezny, K. 1989. Severe spotting of fresh market tomato fruit incited by Corynespora cassiicola after storm-related injury. Plant Dis. 73:1018-1019.

58. White, T. J, Bruns, T., Lee, S., and Taylor, J. 1990. Amplification and direct sequencing of fungal ribosomal RNA genes for phylogenetics. Pages 315-322 in: PCR Protocols: A Guide to Methods and Applications. M. A. Innis, D. H. Gelfand, J. J. Sninsky, and T. J. White, eds. Academic Press, Inc., New York.

59. Zhang, G. M., and Zhang X. G. 2007. Two new species of Corynespora from Guangdong, China. Mycotaxon 99:347-351. 